\title{
空間構造における曲げ剛性の影響 \\ INFLUENCE OF BENDING RIGIDITY IN SHELL-LIKE SPATIAL STRUCTURES
}

\author{
都鎭洙*, 川口 衞** \\ Jin Soo DO and Mamoru KAWAGUCHI
}

\begin{abstract}
Existence of membrane stresses is an essential feature of shell structures which makes them one of the most desirable structural systems, but in practial shell designs, the results always involve certain disturbances on this ideal state, especially in areas adjacent to the boundaries.

Such disturbances are largely dependent on the bending rigidity of the shell. In the analysis of structures such as lattice shells and shells with ribs, the extensional and bending rigidities can be changed independently of each other and, therfore, it seems worthwhile to investigate how shell behaviors are influenced by the relation of these variables for understanding fundmental characteristics of shells. Moreover, a certain type of semi-rigid tension structures, excessive deformation of a roof can be effectively prevented and much freer shape can be also obtained by providing the tension members with a small amount of bending rigidity.
\end{abstract}

Keywords : shell, semi-rigid structure, bending rigidity, thinness ratio シェル, 半剛性構造, 曲げ剛性, 薄さ比

\section{1.はじめに}

シェル構造の力学的有利性は膜応力状態がよ゙の程度支 配的であるかにかかっているが，実際の応力の分布状態 はかなりの擋乱を伴うものであり，その擋乱の程度は支 持条件や曲げ剛性などに多く依存している。重層ラチス シェルなよ゙の解析では，空間において規則的な部材要素 の構成が多いという性質を用いて，連続体近似によって ある力学的特性をもつ連続体シェルとして解析する場合 がある。両者とも根本的な差はなく，等価剛性という評 価を通じて相互変換できるものである。この場合, シェ ルは均質連続体シェルとは異なり，リブ付きシェルのよ うに伸び剛性と曲げ剛性の関係が独立的になる場合があ るので, 両者の関係が構造物に与える影響を検討するこ とは構造物の力学的性質の把握に重要な意味を持つ。

実際半剛性 (Semi-Rigid) 吊り屋根構造などでは構 成要素の伸び剛性および曲げ剛性が独立的に変化してお り，ケーブルの代わりに曲げ剛性を有する材を部分的あ るいは全面的に与えることによって，構造物の荷重に対 する抵抗を高める方法も取られる。本報告は軸対称回転 シェルおよび半剛性吊り屋根構造を解析モデルとして取
り上げ，伸び剛性と曲げ凨性の関係をあるパラメーター で表現するものとし，その変化に伴う構造物の性状の変 化状態を中心に検討するものである。

これらの解析結果は連続体理論に基ついており，軸対 称回転体シェルの場合は，曲線要素を用いた FEM 解 析 (2 章), 半剛性吊り屋根構造の場合 (3 章) は 2 方向 屋根についての直交來標系による基礎微分方程式からの 結果である。

\section{2. 軸対称回転シェル}

\section{1 要素の形状}

一般的に，FEM 解析に用いられる軸対称シェル要素 は子午曲線の形状により直線要素と曲線要素として分け られるが, シェルを网錐体要素の集合体として考えると， 二重曲率を有するシェルの場合, 直線近似のため解の精 度が落ちる。したがっててここでは Stricklin"なよ゙に よって提案された曲線要素 (Curved Element) を用い て解析を行った。回転軸と経線のなす角度を $\phi$ とし， $\phi$ を次式のように経線の長さ $s$ の 2 次式として近似する ( $L$ : 要素の長さ)。

\footnotetext{
本論文の内容の一部は 1991 年日本建築学会大会 (東北) およびIASS Symposium 91 (コペンハーゲン) に発表したものであります。

* 法政大学工学部建築学科 大学院生. 工修 Graduate Student, Dept. of Architecture, Faculty of Engineering,

** 法政大学工学部建築学科 教授・工博 Univ. of Hosei, M. Eng.

Prof., Dept. of Architecture, Faculty of Engineering, Univ. of Hosei, Dr. Eng.
} 


$$
\begin{aligned}
& \phi(s)=\phi_{1}+\alpha_{1} s_{1}+\alpha_{2} s_{1}^{2} \quad\left(s_{1}=s / L\right) \cdots \cdots \cdots( \\
& r(s)=r_{1}+\int_{0}^{s} \sin \phi d s \cdots \cdots \cdots \cdots \cdots \cdots \cdots \cdots( \\
& \alpha_{1}=6 \phi_{0}-4 \phi_{1}-2 \phi_{2}, \quad \alpha_{2}=-6 \phi_{0}+3 \phi_{1}+3 \phi_{2}
\end{aligned}
$$

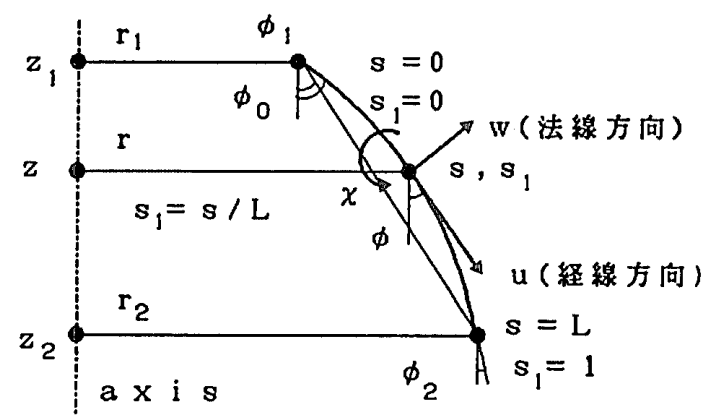

Fig. 1 曲線要素 (Curved Element)

\section{2 ひずみ成分および変位式の仮定}

Koiter $^{51}$ は薄肉シェルの有限変位理論に基づき, シェ ルの中央面上の面内ひずみおよび曲げひずみを次のよう に定義している（ $\omega$ : 回転テンソル， $\psi$ : 中央面におけ る法線の回転ベクトル, $a, b$ : 計量テンソル)。

$$
\begin{aligned}
& \gamma_{\alpha \beta}=\lambda_{\alpha \beta}+\left[a^{x \xi}\left(\lambda_{x \alpha}-\omega_{x \alpha}\right)\left(\lambda_{\xi \beta}-\omega_{\xi \beta}\right)+\left(\phi_{\alpha} \psi_{B}\right)\right] / 2 \\
& \rho_{\alpha \beta}=\left[b_{\alpha}^{x}\left(\lambda_{x \beta}-\omega_{x \beta}\right)+b_{\beta}^{x}\left(\lambda_{x \alpha}-\omega_{x \alpha}\right)\right. \\
& \left.\left.+\psi_{\alpha \mid \beta}+\psi_{\beta \mid \alpha}\right)\right] / 2+b_{\alpha \beta} \psi_{x} \psi^{x} / 2 \\
& -\phi^{x}\left[\lambda_{x \alpha \mid \beta}+\lambda_{x \beta \mid \alpha}-\lambda_{\alpha \beta \mid x}\right] \\
& \lambda_{\alpha \beta}=\left(u_{\alpha \mid \beta}+u_{\beta \mid \alpha}\right) / 2-w b_{\alpha \beta} \\
& t / R \ll t \rho / \gamma \ll \operatorname{Min}[R / t, 1 / t \rho]
\end{aligned}
$$

上式の中， $\gamma_{\alpha \beta}$ が線形化されると $\lambda_{\alpha \beta} に な り ，$ 曲率変 化テンソル $\rho_{\alpha \beta}$ が線形化された場合は，曲率線座標を用 いたときの Sanders ${ }^{6)}$ の式と一致している。軸対称回転 シェルの解析では, 外力 (荷重) および変位を回転 $(\theta)$ 方向にフーリエ級数展開することによって， $\theta$ に対して 変数分離された釣合式が得られる。すなわち，変位関数 を $\theta$ に対してつぎのように仮定する。

$$
\begin{aligned}
u_{n}= & \sum\left\{A_{1}+A_{2} s_{1}+B_{1} s_{1}\left(s_{1}-1\right)\right. \\
& \left.+B_{3} s_{1}^{2}\left(s_{1}-1\right)\right\} \cos n \theta \\
v_{n}= & \sum\left\{A_{3}+A_{4} s_{1}+B_{2} s_{1}\left(s_{1}-1\right)\right. \\
& \left.+B_{4} s_{1}^{2}\left(s_{1}-1\right)\right\} \sin n \theta \\
w_{n}= & \sum\left\{A_{5}+A_{6} s_{1}+A_{7} s_{1}^{2}+A_{8} s_{1}^{3}\right\} \cos n \theta
\end{aligned}
$$

$u, v, w$ は要素の変位の直交 3 成分であり, $u$ が経線 方向, $v$ が緯線方向, $w$ が法線方向の成分である。また 要素の回転角 $\chi$ は変位を用いて次のように表される。

$$
\chi_{n}=\left\{d w_{n} / d s_{1}+u_{n} d \phi / d s_{1}\right\} / L
$$

ここで $B_{i}(i=1 \sim 4)$ は末定係数であり， $s_{1}=0,1$ にお いては変位 $u, v$ とは無関係である。したがって, 係数 $B_{i}$ は要素を組み立てる前に縮約される内部自由度であ る。またシェルに作用する荷重に対しても変位の場合と 同様にフーリエ級数展開を行う。これらの要素の未定係
数ベクトルに関する判性方程式はつぎのようになる。

$$
\left[\begin{array}{ll}
{\left[k_{A A}\right]} & {\left[k_{A B}\right]} \\
{\left[k_{B A}\right]} & {\left[k_{B B}\right]}
\end{array}\right]\left\{\begin{array}{l}
\{A\} \\
\{B\}
\end{array}\right\}=\left\{\begin{array}{l}
\left\{f_{A}\right\} \\
\{0\}
\end{array}\right\}
$$

ここで $\{B\}^{r}=\left[\begin{array}{llll}B_{1} & B_{2} & B_{3} & B_{4}\end{array}\right]$ の項は全要素を重ね合わ せる前に消去 (縮約) することができ，結果的につぎの ように表される。

$$
\left[\left[k_{A A}\right]-\left[k_{A B}\right]\left[k_{B B}\right]^{-1}\left[k_{B A}\right]\right]\{A\}=\left\{f_{A}\right\}
$$

この縮約 (condensation) は $B_{i}(i=1 \sim 4)$ が節点にお ける変位に影響しないということの結果として目然に行 われるものであり，要素の剛性マトリックスは一般の場 合 $(8 \times 8)$ に, 軸対称荷重の場合 $(6 \times 6)$ に縮まる。( 8$)$ 式を節点変位ベクトルおよび等価節点力ベクトルで表せ ば最終的な要素剛性マトリックスが得られる。

\section{3 回転体における曲げ剛性の影響}

解析において回転シェルは厚さ方向に均質で放ると見 なされ，曲げ中立軸がシェル厚中央であると考光る。こ こではシェルの伸び凮性と曲げ剛性の関係をあるパラ メーターとして表現するものとし，シェルにおける伸び 岡性に詨して曲げ岡性のみを独立的に変化させることに よって生じるシェルの力学的挙動の変化について検討す る。線材の解析における断面二次半径 (回転半径) の概 念を連続体シェルに適用させた係数 $i_{0}$ を導入して，伸 び剛性と曲げ風性の関係が，次のようなパラメーター $\beta$ (thinness ratio：薄さ比) として与えられるものとし， 連続体回転直交異方性シェルの概念から解析を行う。

$$
\begin{aligned}
\beta_{K}=\frac{r_{0}}{\left(i_{0}\right)_{K}}= & \sqrt{\frac{12\left(t_{E}\right)_{K} r_{0}^{2}}{\left(t_{B}\right)_{K}^{3}}}\left(i_{0}\right)_{K}=\sqrt{\frac{\left(t_{B}\right)_{K}^{3}}{12\left(t_{E}\right)_{K}}} \\
& (K=1,2) \ldots \ldots \ldots \ldots \ldots \ldots \ldots \ldots \ldots \ldots \ldots \ldots \ldots \ldots \ldots
\end{aligned}
$$

ここで $t_{E}, t_{B}$ はそれぞれ伸びおよび曲げに関する有効 シェル厚， $r_{0}$ は回転体の底辺部の半径を表しており， 添え字 $(K=1,2)$ は一般に経線方向ならびに緯線方向 に変化するものと考える。 $\beta=\infty$ の場合は，シェルにお ける曲げ㴊性が存在しなく，面内力のみで作用荷重に抵 抗する膜応力状態に対応している。均質等方性の連続体 シェルの場合は，ポアソン比は 1 つに定まる量であるこ とに対して，異方性のときは曲げに関するものと伸びに 関するものが異なる場合があるが，この解析ではポアソ ン比の影響を無視して解析上の簡略化を行う。饮からは 幾つかの回転シェルを取り上げて, 伸びに関するシェル 厚に対して $t_{E 1}=t_{E 2}=t_{\varepsilon}$ とし, 主にパラメーダー $\beta$ が シェルの変形並びに応力の分布に及ぼす影響について述 ベる。なお，この章では解析に用いるシェルの諸寸法に 対して無次元化を行っており，変位成分および忘力の単 位はそれぞれ $[: \mathrm{m}] ，[: \mathrm{t} / \mathrm{m}]$ に対応している。

\section{（1）円筒および鼓形，樽形シェル}

子午曲線 (平面曲線) が円弧であり，その形状がパラ メーター $\tau$ で表される等方性殻 $\left(\beta_{1}=\beta_{2}=\beta\right)$ に対する 結果について検討する。 


$$
\tau=r_{0} / R \quad(\tau<1)
$$

$r_{0}:$ 底辺部の半径

$R:$ 経線方向の曲率半径

下端部固定支持の $\tau=0$ (円筒形) の形状を持つ回転 曲面が $p_{n}=p \cos n \theta$ のような荷重分布を受ける場合, パラメーター $\beta$ の変化による応力および変位の分布状 態を調べる。harmonic num. $n=0$ のような一樣内圧を 受ける場合は, 解析範囲内で, $\beta$ の変化による影響が境 界付近のごく狭い領域に限定されるため, $n=1,2$ の荷 重分布に対する法線方向の変位 $w$ と周方向の忘力 $N_{2}$ の 分布状態を.Fig. 2 に示す。変位の分布を見ると, $n=1$ の場合は $\beta$ の影響が境界近傍に限定されるのに対しで， $n=2$ の場合の $\beta$ の影響範囲は境界から離れてより広い 領域になり，パラメーター $\beta$ の值が小さくなるにつれ て変位も相当に減少している。周方向応力 $N_{2}$ の分布に おいても同じ傾向が現れており, 特に $\beta$ がある值以下 になると $(n=2)$ ，応力の減少状態が一段と大きくなる ことが分かる。また作用荷重の分布状態にもかかわらず， $\beta$ の減少とともに境界付近の引張応力が圧縮応力に変化 している。このような変化パターンは経線方向に曲率を 有する回転曲面が自重の作用を受ける場合，より明確に なる。 $\tau=0.6$ (樽形：Barrel Type）の場合の解析結果
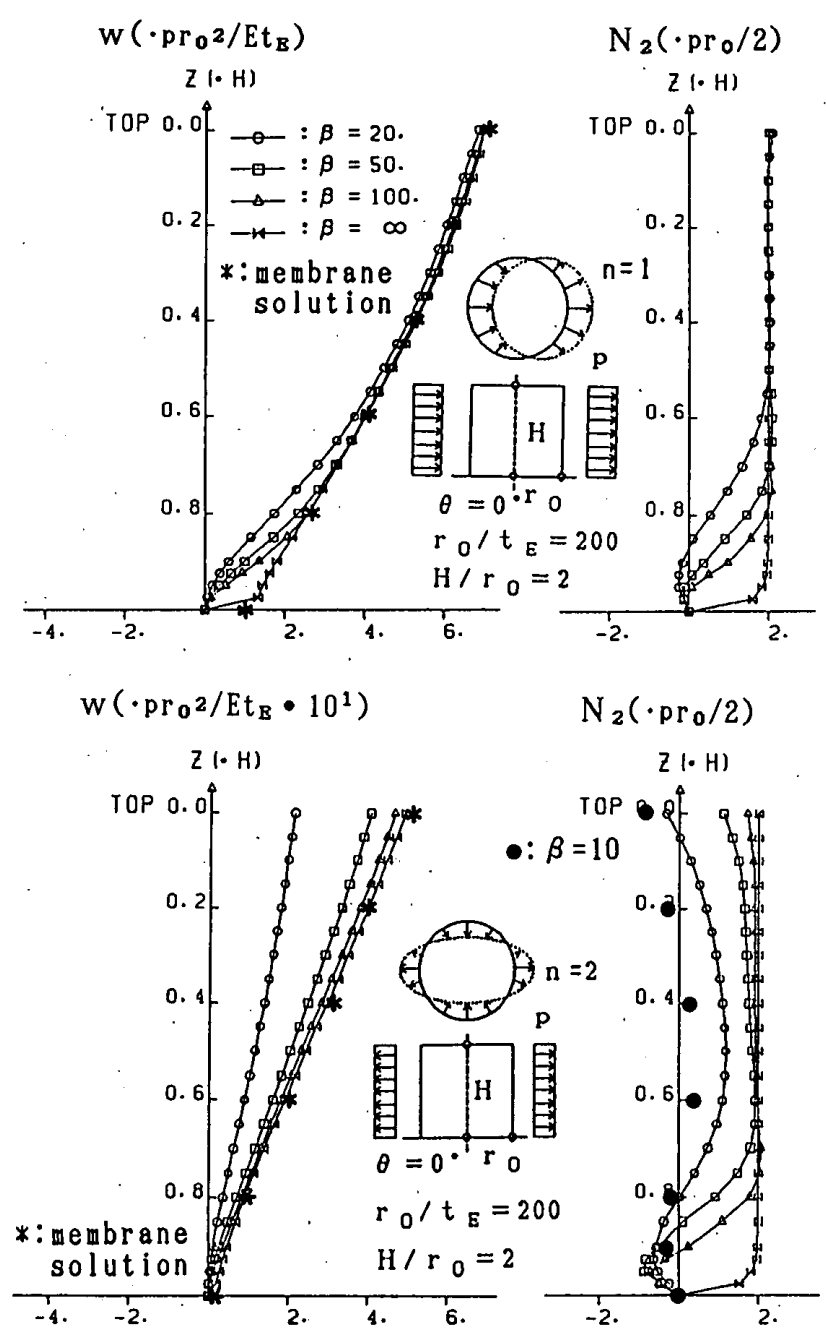

Fig. 2 変位および応力の分布図 (筒形; $\tau=0$ )
をFig. 3 に示す。このような場合, 薄さ比 $\beta$ の影響は（解 析籁囲内), 経線方向よりは法線方向に大きく現れる。 結果から分かるようにパラメーター $\beta$ の影響は TOP 部 ではほとんど生じないのに対して境界近傍では $\beta$ の変 化により，変位および志力は非常に異なる分布を示して いる。すなわち，曲げ抵抗がなく面内力のみで作用荷重 に抵抗する $\beta=\infty$ の場合の分布に比べて, $\beta$ の值が減 少するに従って, 変位および応力 $\left(w, N_{2}\right)$ の減少状態 は境界部付近でより大きくなっている。

このような変化パターンは回転体の経線方向の曲率が 負である場合（鼓形：Waisted Type）でも見られる。 $\tau$ $=-0.6$ の場合の解析結果 (Fig. 4) を見ると分かるよ うに，薄さ比に相当するパラメーター $\beta$ の影響は依然 として TOP 部よりは境界部に大きく現れており，その 変化性状も $\tau=0.6$ の場合とほぼ同じ傾向を示してい る。このような性状はいろんな諸要素（支持条件，作用 荷重状態なよ゙を含む）により，異なる傾向を示す場合も ある。 $\tau= \pm 0.6$ の解析モデルに対して薄さ比 $\beta$ の変化 による最大変位の変化状態を Fig. 5 に示す。固定支持

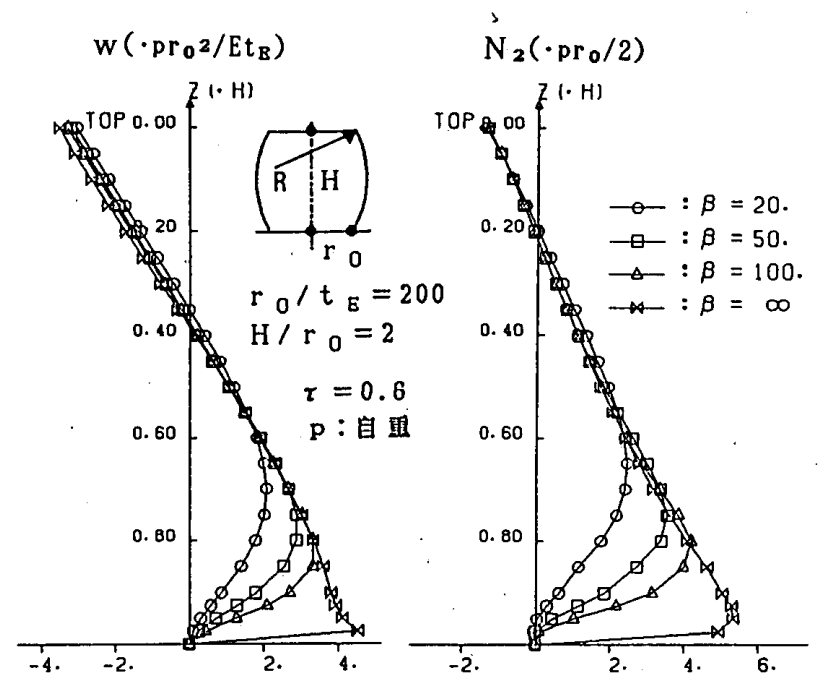

Fig. 3 変位および応力の分布図 (樽形; $\tau=0.6$ )

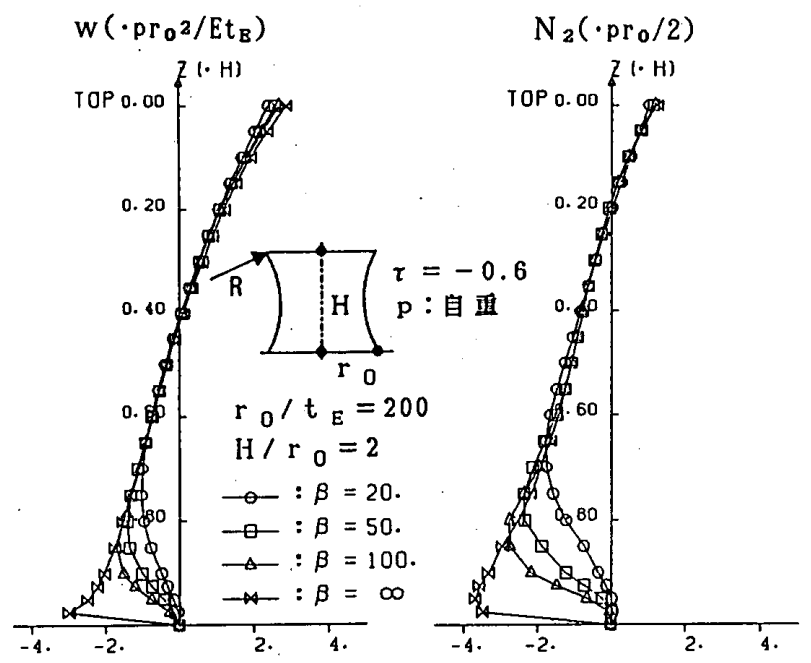

Fig. 4 变位および応力の分布図 (鼓形; $\tau=-0.6$ ) 


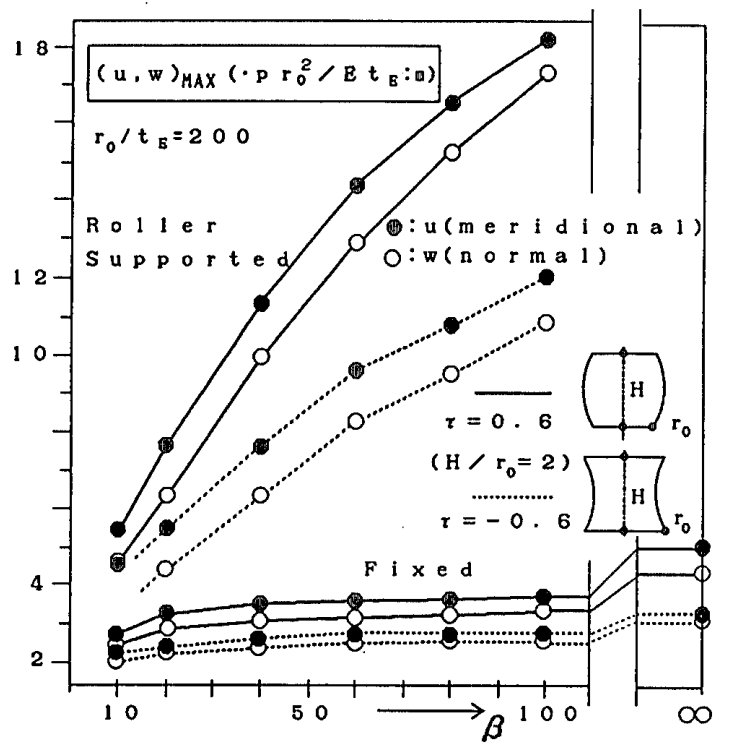

Fig. $5 \beta$ の変化による最大変位の変化図

の場合における $\beta$ による最大変位の変化状態と比べて, ローラー支持の場合の $\beta$ による最大変位の変化範囲は 非常に大きく，このような場合シェルにある程度の曲げ 剛性を持たせる方が、シェルにおける変形の低減により 効果的であるといえる。

(2) 長円回転面 (Rotational Ellipsoid)

ここからは解析モデルとして，自重の作用を受ける境 界固定支持の長问回転面を取り上げて, パラメーター $\beta$ の変化による変形および応力の分布状態を調べる。

$$
e=\left(r_{0}^{2}-H^{2}\right)^{1 / 2} / r_{0} \text { ：離心率 }
$$

$e=0.87$ の場合における法線方向の変位および周方向の 応力分布がFig. 6 に示されている。変化パターンとし ては前節とほぼ同じである。すなわち，パラメーター $\beta$ の値が小さくなるにつれてシェルにおける引張応力およ び変位は境界部より次第に減少する傾向を示している。 $\beta=20$ の場合になると, シェルの殆に゙の領域にわたって 圧縮力のみになっている。 $e=0.5,0.7,0.8$ のような 形状を有する長円回転面が自重の作用を受ける場合に対

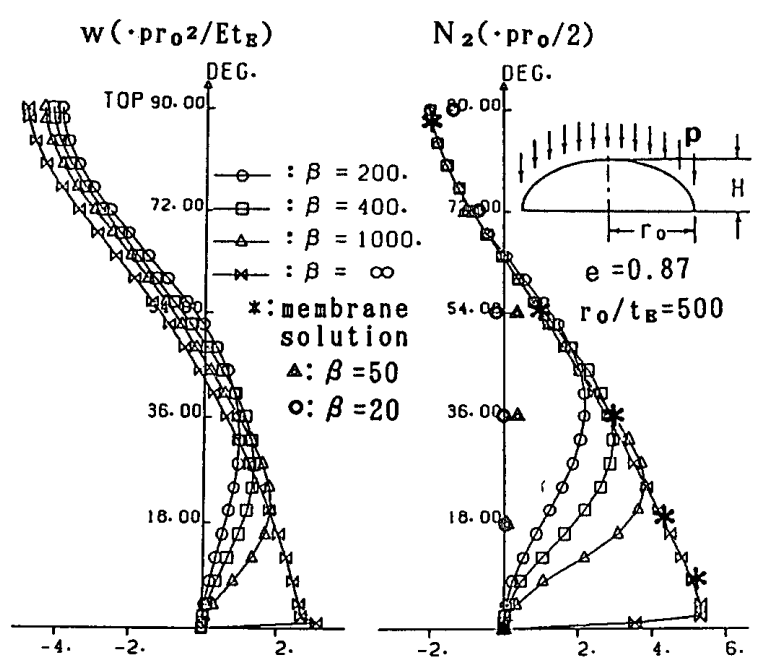

Fig. 6 変位および㐫力の分布図（長円回転面）
して, $\beta$ の変化による法線方向変位の変化状態を Fig. 7 に示す。この結果は薄さ比の変化によるシェルの力学的 性状の変化が大きいと思われるある特定点 $\left(\phi=8^{\circ}\right)$ に おけるものであるが，薄さ比の減少に伴う変位の减少状 態が非常に大きいことが分かる。

(3) $\beta_{1} \neq \beta_{2}$ の場合

今までの解析は，与えられた曲げ剛性が等しい均質等 方性 $\left(\beta_{1}=\beta_{2}=\beta\right)$ シェルの場合の結果である。 $\beta_{1} \neq \beta_{2}$ の上うに両方向 $(s, \theta)$ のパラメータ一が独立的に変化す る場合については回転直交異方性シェルとして解析され る。このような場合の応力解析では, 構成パラメーター $\beta$ の独立的変化による構造性能の優劣を比較梌討するの が重要な内容になる。結果（Fig. 8) から分かるように, 自重の作用を受ける長円回転面の場合については, $\beta_{2}(\theta$ 方向）上りは $\beta_{1}(s$ 方向）の変化がシェルの力学的挙 動に及ぼす影響が大きく, $\theta$ 方向の曲げ剛性の変化によ る効果は解析範囲内で，ほとんど見られないことが分か り，s方向のみ大きい曲げ岡性をシェルに持だせること が，このような荷重条件では効率的であるといえる。し かし荷重の分布状態によっては $\beta_{2}$ の影響も大きく現れ る場合がある (Fig. 9 10)。特に $p_{n}=p \cos 2 \theta(n=2)$

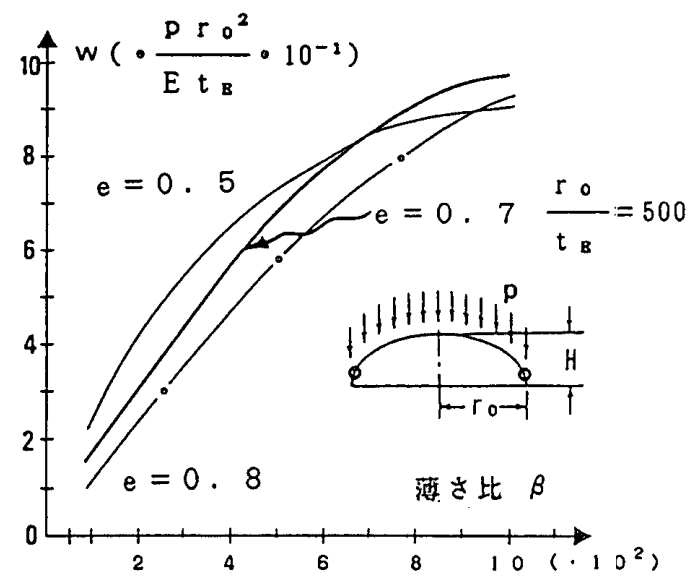

Fig. 7 シェルの形状と薄さ比の関係

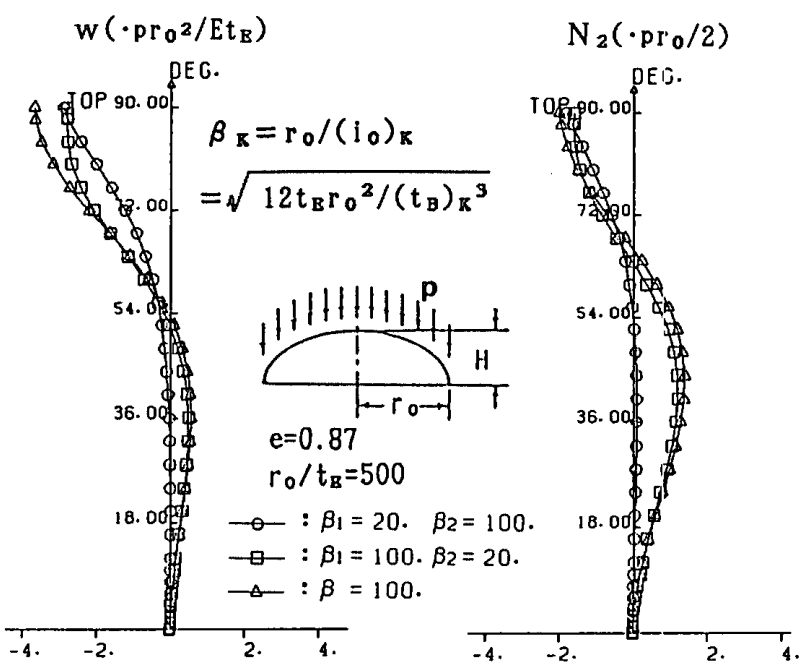

Fig. 8 変位书よび応力の分布図（長円回転面; $\beta_{1} \neq \beta_{2}$ ) 


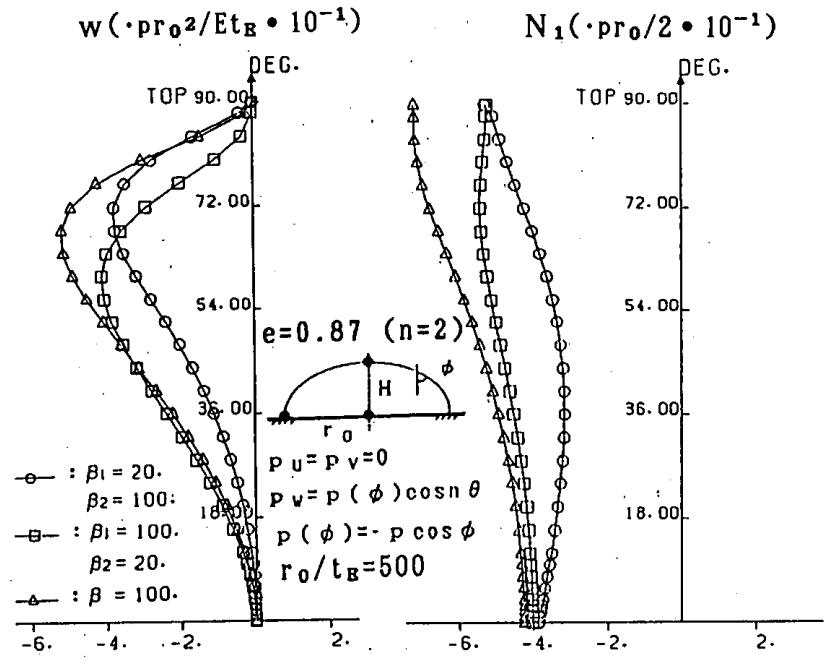

Fig. 9 変位および応力の分布図（長円回転面; $\beta_{1} \neq \beta_{2}$ )

のような荷重分布を受ける円筒形シェルの場合

(Fig. 10) では， $\beta_{1}$ よりは $\beta_{2}$ の影響が大きく現れてお り，シェルに作用する荷重の分布状態によってシェルの 力学的挙動は大きく変化することが分かる。

\section{(4) 非線形解析}

座屈荷重の解析や大たわみを伴う変形解析には非線形 解析が必要となってくるが, その非線形殼理論は線形殻 理論に比べて非常に複雑になり, その解析的処理も一段 と難しくなる。パラメーター $\beta$ の値が大きくなるにつ れて (曲げ剛性が小さくなる), 非線形解と線形解との 差が大きく現れることが予想される。ここでは Koiter ${ }^{5)}$ の有限変位理論（Small Finite Deflection）に基づき, 前述の解析モデルに対して非線形解析の結果について検 討するが，（4）式の曲げひずみ項に関しては線形化さ れた Sanders ${ }^{6}$ の式を用いて解析を行った。4 次以上の 微小項を無視した非線形ひずみによるひずみエネルギー を $U_{N L}$ として表すと, 要素の力の釣合式は全体座標系に
おいて次のように表される。

$$
\left.\left\{Q^{*}\right\}_{E}=\left[K^{*}\right]_{E} \mid \delta^{*}\right\}_{E}+\left\{\partial U_{N L} / \partial \delta^{*}\right\}_{E}
$$

ただし $\left\{\delta^{*}\right\}$ は全体座標系におりる変位ベクトル，\{Q*|は 外力ベクトル，[$\left.K^{*}\right]$ は剛性マトリックスを表している。 (5) 式の係数 $\left\{A_{i}\right\}(i=1 \sim 8)$ を要素の変位成分 $\left\{\delta_{i}^{*}\right\}_{E}(i$ =1〜8）で次のように表すことができる。

$$
\{A\}=[T A]\left\{\delta^{*}\right\}_{E}
$$

ここでマトリックス $[T A]$ は要素の節点位置 $s_{1}=0,1$ で 評価されるため $(5)$ 式の末定係数 $\left\{B_{i}\right\}(i=1 \sim 4)$ は 自動的に排除される。(13) 式から $\partial A_{j} / \partial \delta_{i}^{*}=T A_{j i}(i, j$ =1〜8）の関係で表されるから（12）式の要素のひずみ の非線形項による力を次式のように表し，計算を比較的 簡略化した。

$$
\left\{\partial U_{N L} / \partial \delta^{*}\right\}_{E}=[T A]^{T}\left\{\partial U_{N L} / \partial A\right\}_{E}
$$

この非線形問題に対する数值解法としては, NewtonRaphson 法が採用されており，要素の数值積分におい てはNewton-Cotes の10 点公式が用いられた。Fig.11 はある断面を有する長円回転面 $(e=0.9)$ に対して, 薄さ比の変化による荷重-変位曲線が示されているが, $\beta$ の值が大きくなるにつれて線形解と非線形解との差が 大きくなることが分かる。今回の解析は曲げに関する有 効厚さを独立的に変化させる場合のものであり, 非線形 解析における荷重パラメーターを伸びに関する肉厚 $t_{E}$ との関係で, $\left\{E t_{E} / p r_{0}\right\}$ として表現するものとする。自 重の作用を受ける長们回転面の場合（荷重パラメーター $E t_{E} / p r_{0}=7500$ : Fig. 11 の縦軸上の「a」荷重レベル) におけるシェル境界近傍の応力の分布（Fig. 12）を見 ると, 薄さ比 $\beta=1500$ のときは線形解と非線形解との 差がほとんどないのに対して， $\beta=3000$ の場合はその 解の差がより顕著に現れており，与えられた曲げ剛性に 関するファクターの変化に大きく影響されることが分か る。このような傾向は，自重の作用を受ける鼓形（Wa-
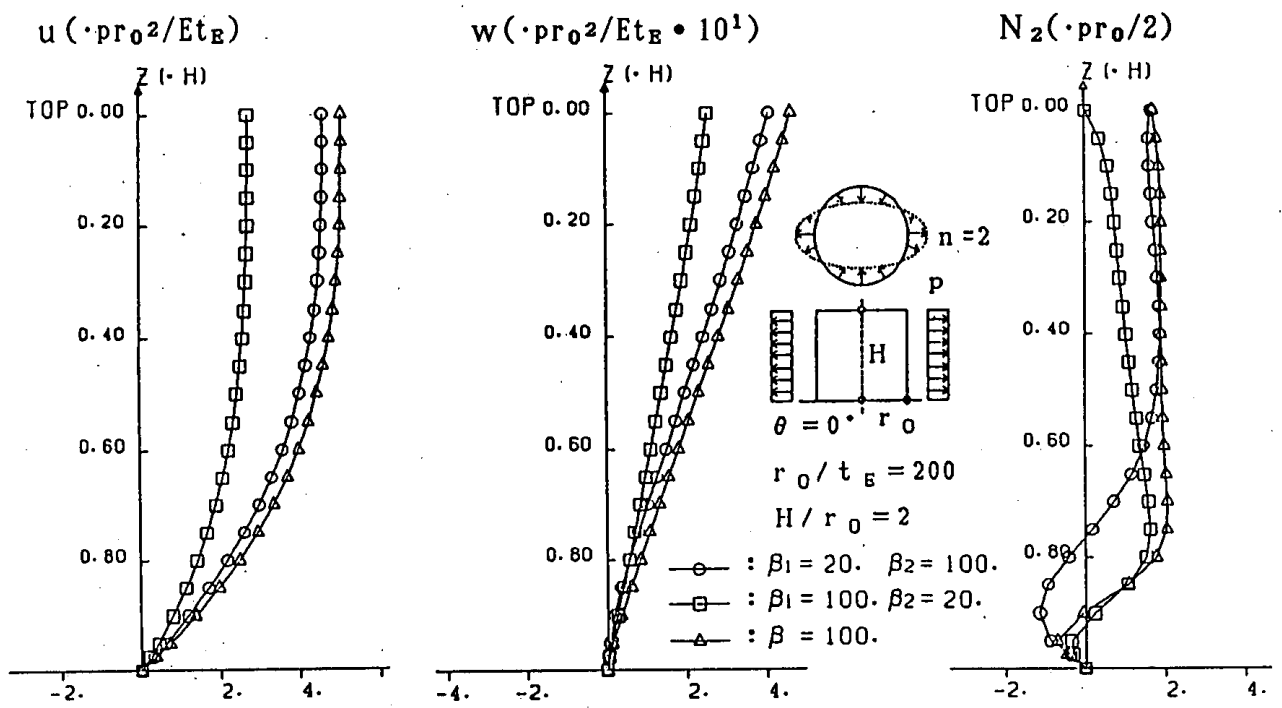

Fig. 10 変位および芯力の分布図 (円筒形; $\beta_{1} \neq \beta_{2}$ ) 


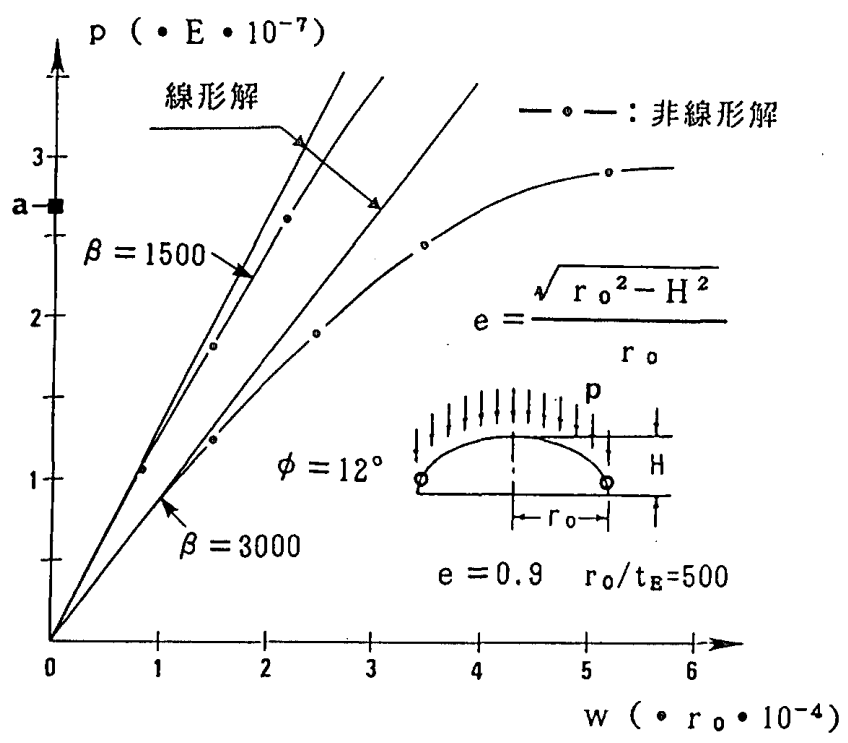

Fig. 11 荷重-変位曲線

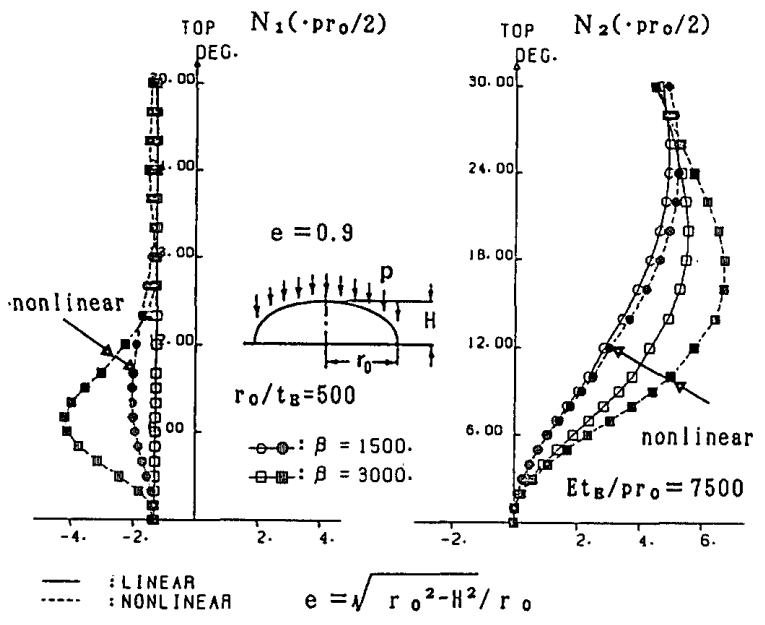

Fig. 12 合応力の分布図

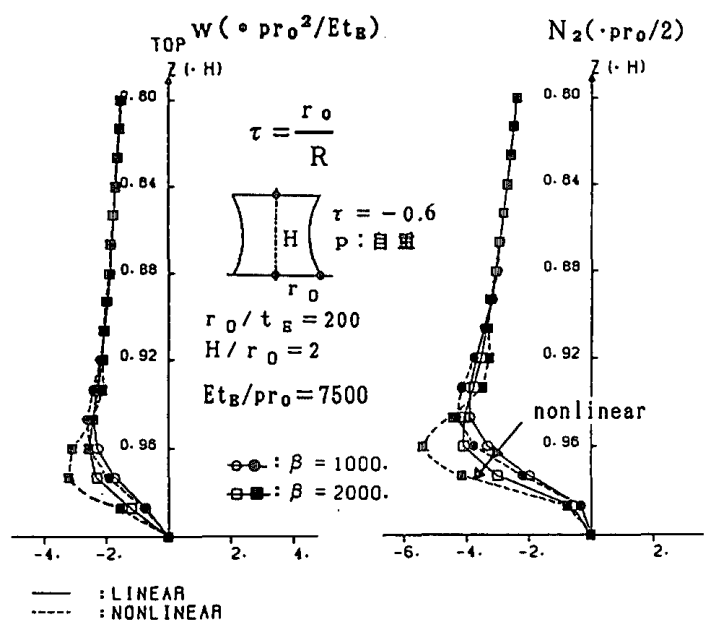

Fig. 13 変位および応力の分布図

isted Type : $\tau=-0.6)$ の回転曲面でも見られており

(Fig. 13), 薄さ比 $\beta$ の值が減少するに従って, 線形解 と非線形解との差が大きくなっていることが分かる。

\section{3. 半剛性構造 (Semi-Rigid Structure)}

Tension Structure（張力構造）は外力の作用のもと で生じる力が引張力のみであり, 曲げモーメントおよび 圧縮力は伝達せず，座屈現象などは起こらない構造を意 味する。引張力のみで作用荷重に抵抗するという有効性 もあるが，その引張力が境界構造に達すると，そこで非 常に大きい水平成分（水平張力）を処理しなければなら ない。また逆対称成分を含むような部分荷重などによる 変形を不当に大きくしないため, 初期荷重およびプレス トレスを増加して追加荷重の影響を減少させる方法もあ るが, それは引張材以下境界構造に至る部材の断面の増 加を要求するので不経済になりやすく, 決して望ましい ことではない。このため部分的あるいは全面的に引張材 に曲げ剛性を与えて構造物の曲率変化に対する抵抗を高 める方法が取られる。純粋な引張状態での張力構造の曲 面の形状は張力の分布と境界の形状によって決定される が，このように材に曲げ剛性を与えると,より自由な形 態の構造形式の確保も可能であり, 屋根面の剛性の確保 だけでなく造形的, 経済的であるという面から広い範囲 で応用できる新しい構造形式のひとつである。このよう な目的を満たすため, 吊り屋根曲面にわずかな曲け剛性 を与えたものをここでは半剛性吊り屋根と呼ぶことに する。

\section{1 解析概要}

このような吊り屋根構造の解析法としては大別して “連続系解析”之“離散系解析” の 2 通りのアプローチ が考えられる。前者についてはF.K. Schleyer ${ }^{121: 131}$ が 2 方向ケーブル屋根についての直交座標系による解析を 与えており，後者についてはSiev \& Eidelman' ${ }^{151} に よ$ る解析法なゼがあるが, 本質的な差はなく等価剛性の評 価を通じて相互変換できるのである。ここでは連続体概 念に基づいて屋根面を構成材と等価断面積をもつ薄膜面 に置換し，連続面として扱う。ここで，Fig.15のよう な吊り屋根構造の最も代表的な任意の長方形平面を有す る鞍形の双曲放物面 (HP 曲面) を解析モデルとして取 り上げて, 曲げ剛性の変化による変形および張力の変化 状態の結果について検討する。変形前において, 屋根面 はプレストレスおよび初期荷重 $\left(p_{0}\right)$ のみを受けて初期 形状を示すものと考える。その屋根面の初期状態を $z$ とすると座標軸と一致する平面曲線から形成される吊り 屋根構造における釣合方程式は, 載荷後次のような式で 表される $\left({ }^{\prime}=\partial / \partial X,{ }^{\circ}=\partial / \partial Y\right)$ 。

$$
\left.\begin{array}{l}
h_{X}^{\prime}+q_{x}=0, \quad h_{Y}^{\circ}+q_{Y}=0 \\
h_{x} z^{\prime \prime}+H_{X 0} w^{\prime \prime}+h_{Y} z^{\cdot}+H_{Y 0} w \cdot+m_{X}^{\prime \prime} \\
\quad+m_{Y}+p_{0}-q_{X} z^{\prime}-q_{Y} z^{\circ}=0
\end{array}\right\}
$$

ここで， $H_{x 0}, H_{y_{0}}$ はそれぞれの方向における単位長さ当 たりの初期張力, $m_{x}, m_{\mathrm{r}}$ は要素の曲げモーメントの変 化を表している。また吊りおよび押え方向の張力変化の 
水平成分 $h_{X}, h_{Y}$ は次の.ようになる。

$$
\begin{aligned}
& h_{X}=B_{X}\left(u^{\prime}+z^{\prime} w^{\prime}\right)=C_{1}(Y)-\int_{0}^{x} q_{X} d X \\
& h_{Y}=B_{Y}\left(v^{\circ}+z^{\circ} w^{\circ}\right)=C_{2}(X)-\int_{0}^{Y} q_{Y} d Y \\
& B_{X}=E A_{X} /\left\{1+\left(\dot{z}^{\prime}\right)^{2}\right\}^{3 / 2} \\
& B_{Y}=E A_{Y} /\left\{1+\left(z^{\circ}\right)^{23 / 2}\right.
\end{aligned}
$$

(16) 式についてケーブルの全長にわたって積分を行う 之， $C_{1}(Y)$ は結局次のように求められる。

$$
\begin{aligned}
C_{1}(Y)= & t_{X}\left\{\int\left[B_{x}^{-1} \int_{0}^{x} q_{X} d X\right] d X+\left[z_{E}^{\prime} w_{E}-z_{S}^{\prime} w_{S}\right]\right. \\
& \left.+\left[u_{E}-u_{S}\right]-\int z^{\prime \prime} w d X\right\} \cdots \cdots \cdots \cdots(17)
\end{aligned}
$$

ただし，(17）式の添字 $E ， S$ はそれぞれ境界 $(X=$ $\left.\pm L_{x} / 2\right)$ での值を意味する。 $Y$ 方向についても同じょう に積分して $C_{2}(X)$ を求め, (15) 式の $Z$ 方向の釣合式に 代入して境界での変位成分が零であると仮定すると, 結 局つぎのような式になる $\left(1 / t_{X}=\int d X / B_{X}, 1 / t_{Y}=\int\right.$ $\left.d Y / B_{Y}\right)_{\text {。 }}$

$$
\begin{aligned}
& z^{\prime \prime} t_{x} \int z^{\prime \prime} w d X+z \cdot t_{Y} \int z \cdot w d Y-H_{x 0} w^{\prime \prime} \\
& -H_{Y_{0}} w^{*}+D_{X}\left(w^{\prime \prime}\right)^{\prime \prime}+D_{\curlyvee}\left(w^{*}\right)^{* *}=p(X, Y)
\end{aligned}
$$

ただし $D_{X}, D_{Y}$ はそれぞれ吊りおよび押えケーブルの 曲げ剛性を表しており， $q_{X}=q_{r}=0$ の場合は荷重項 $p(X, Y)=p$ として簡略化される。一方, 初期張力 $H_{\mathrm{r} 0}$, $H_{x 0}$ の間には曲面の初期状態においてつぎのような関係 が成立する。

$$
H_{X 0} \rho_{X}=H_{Y 0} \rho_{Y}, \quad H_{x 0} f_{X} L_{Y}=H_{Y 0} f_{Y} L_{X}
$$

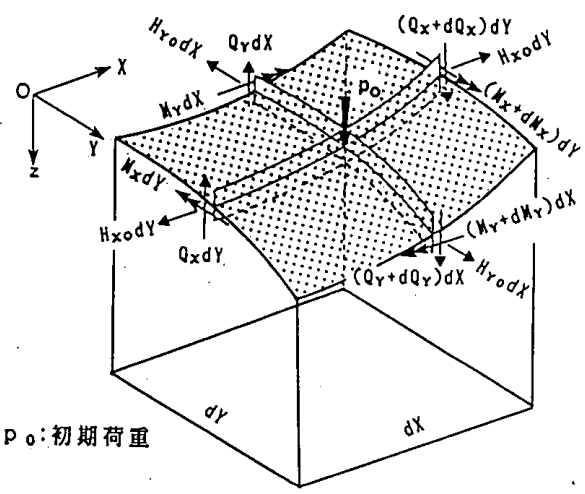

Fig. 14 半判性構造
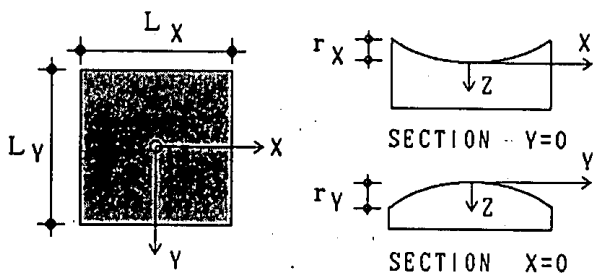

$Z=\frac{1}{2}\left[-\rho_{X} X^{2}+\rho_{Y} y^{2}\right]$

Fig. 15 解析モデル (HP 曲面)
また，ケーブルネットのサグおよびライズは次のように 表される。

$$
r_{X}=\rho_{X} L_{X}^{2} / 8, \quad r_{Y}=\rho_{Y} L_{Y}^{2} / 8
$$

ただし $f_{X}, f_{Y}$ はそれぞれ屋根面のサグおよびライズ比 を表しており， $\rho_{X}, \rho_{Y}$ は屋根面の頂点における曲率の絶 対値を示している。また屋根面に作用するプレストレス および 2 方向の諸寸法（スパンおよび断面積など）を無 次元化された比として表し，前章と同様に材の伸び岡性 と曲げ剛性の関係を薄さ比 (thinness ratio) で表現する。

$$
\begin{aligned}
& \left.\varepsilon=H_{x 0} / E A_{X} \text { (：初期ひずみ }\right) \\
& \beta_{x}=L_{X} / i_{x}=\sqrt{E A_{x} L_{x}^{2} / D_{X}} \\
& \beta_{Y}=L_{Y} / i_{Y}=\sqrt{E A_{Y} L_{Y}^{2} / D_{Y}}
\end{aligned}
$$

上記の関係を（18）式に代入して差分形式で表すものと し，薄さ比の変化に伴う構造物の静的挙動について調べ る。

\section{2 解析結果}

一般的に吊り屋根構造は作用荷重パターン，サグおよ びライズ比，プレストレスなどによって，その力学的挙 動は大きく変化する。以下の結果（Fig.16１8）は初 期ひずみ $\varepsilon=1 / 10^{3}$ のプレストレスを受ける正方形平面 を持つ吊り屋根構造の, パラメーター $\beta\left(\beta_{X}=\beta_{Y}=\beta\right)$ の変化による変形および張力の変化図である。

全面等分布荷重 $p$ の作用を受ける場合 (Fig. 16), こ の種の荷重状態では伸び変形が支配的であり, 屋根面の 曲率変化が小さく生じるため, 曲げ剛性の変化による鉛 直変位および張力変化の水平成分 $h_{x}$ の変化はそれほぼ 大きくないが, 変形モードから分かるように, $\beta=\infty$ (曲 げ岡性 0)の場合は, 同様の荷重分布に対して生じるア一
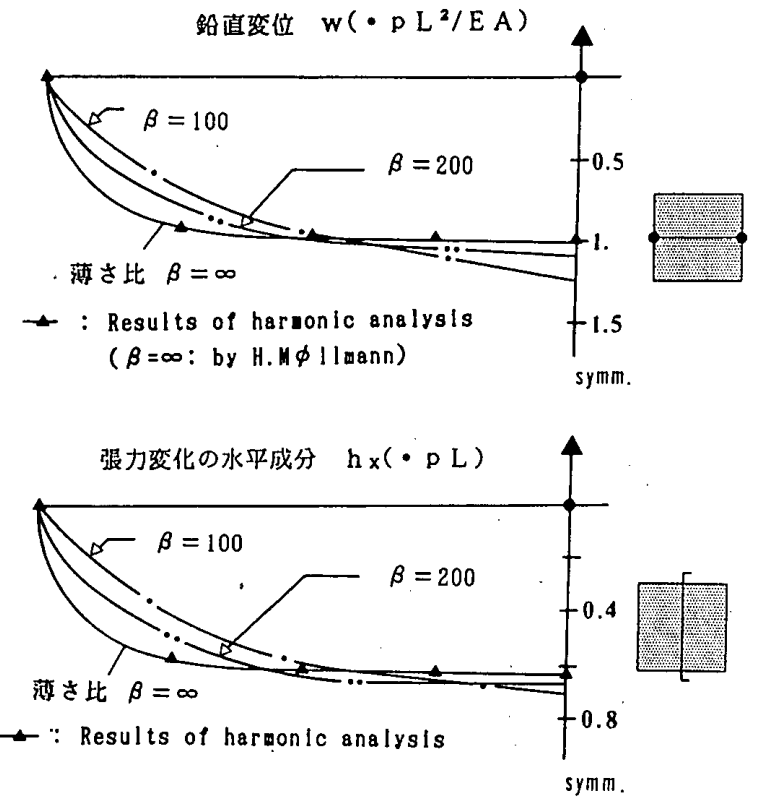

$\mathrm{L}_{\mathrm{X}}=\mathrm{L}_{\mathrm{y}}=\mathrm{L}$

$\mathrm{A}_{\mathrm{x}}=\mathrm{A}_{\mathrm{Y}}=\mathrm{A}$

$f_{X}=f_{Y}=0.10$

$\mathrm{H}_{0} / \mathrm{E} \mathrm{A}=10^{-3}$

Fig. 16 全面荷重 (Full Loading) 


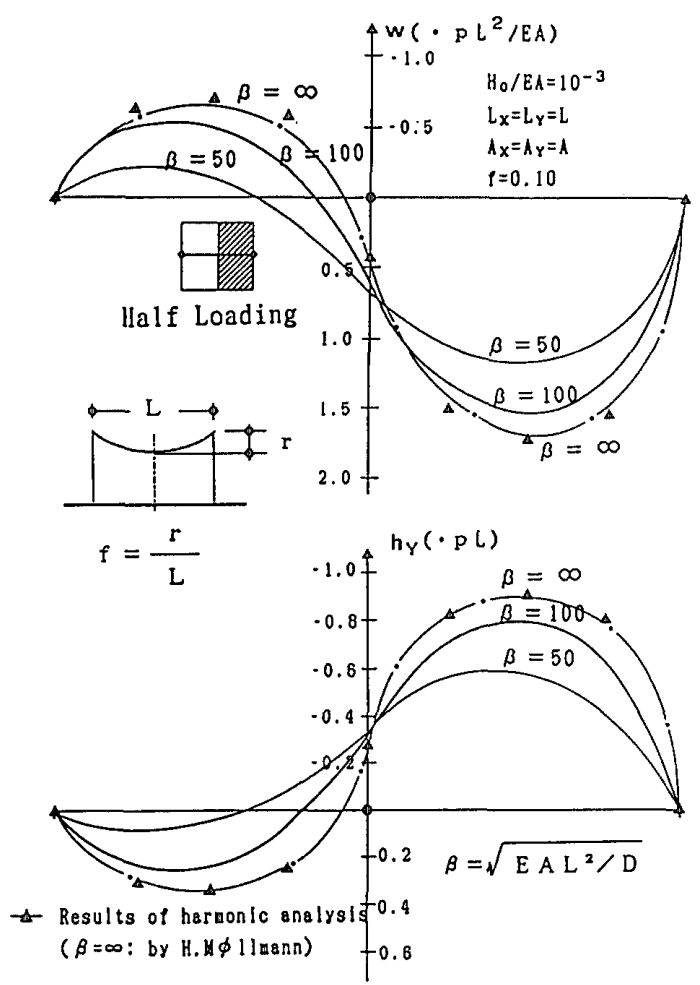

Fig. $17 \beta$ の変化による鉛直変位および張力変化の水平成分の 分布図 (Half Loading)

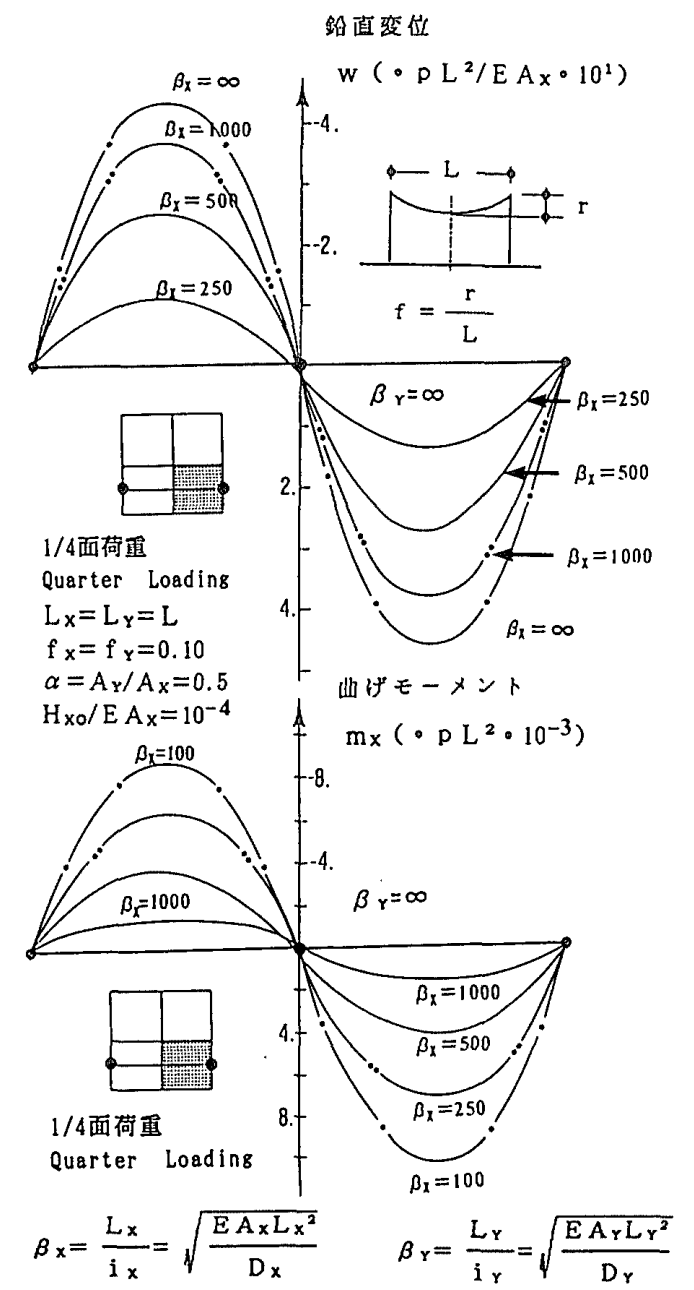

Fig. $19 \beta$ の変化による鉛直変位および曲げモーメントの分布 図 (Quarter Loading)

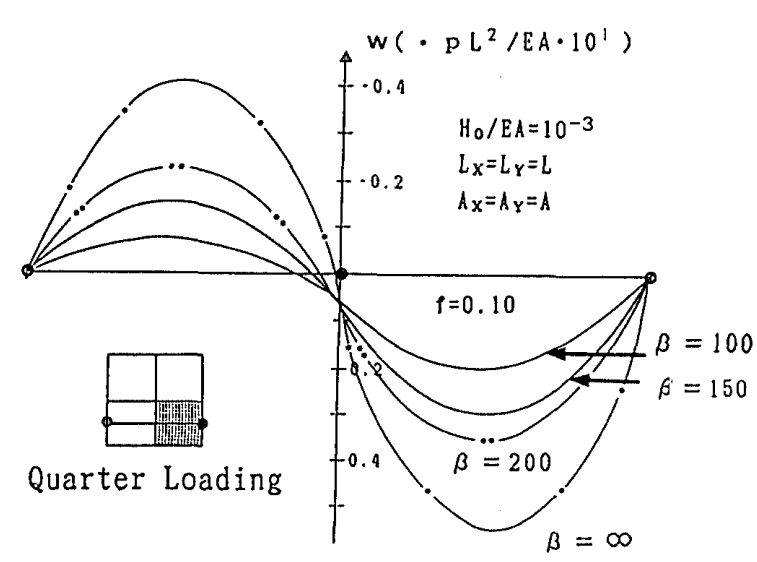

Fig. 18 1/4 面荷重 (Quarter Loading)
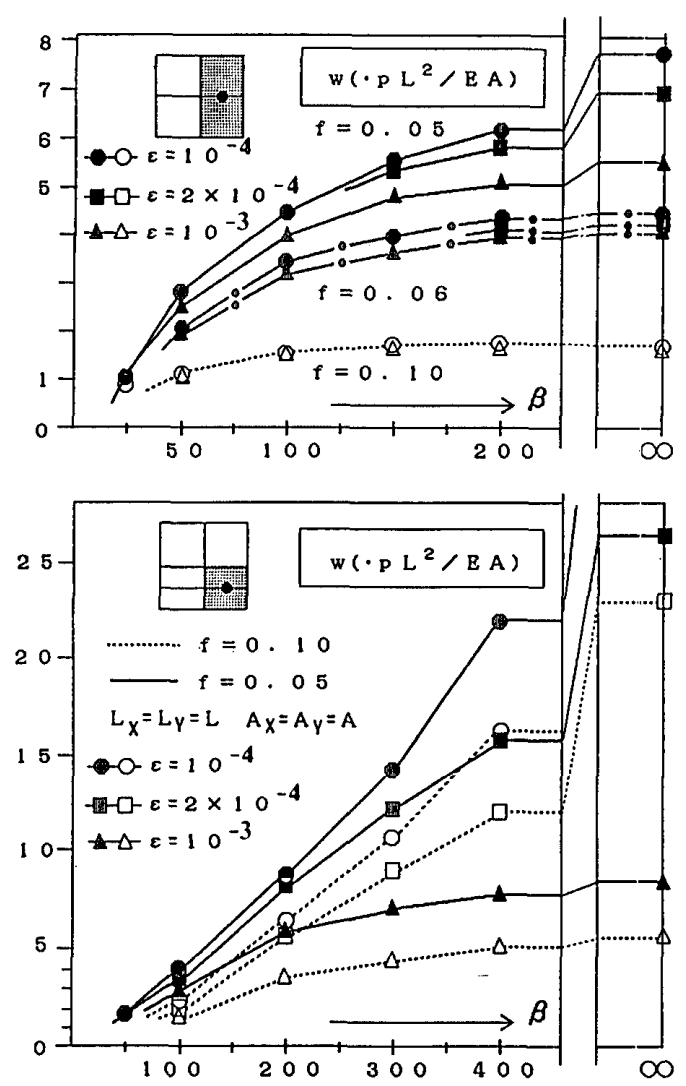

Fig. $20 \beta$ の変化による鉛直変位の変化図

チの変形に見られるような分布(これをアーチ羏あるい はその形状を具体的に表す意味で鍋底形と呼ぶ）を示す のに対して, 薄さ比 $\beta$ の值が減少するに従ってその分 布曲線は次第に通常の梁の変形に相当する梁形(曲げ形) に変化している。

半面あるいは $1 / 4$ 面荷重分布状態になると (Fig. 17 ～18）パラメーター $\beta$ の影響が一段と大きく涀れる。 特に $1 / 4$ 面荷重のような局部的に偏在している荷重分布 の場合, 薄さ比 $\beta$ の減少に伴う変形の変化が更に大き く現れる。このような部分荷重は，それぞれ逆対称荷重 ケースの重ね合わせによって得ることができ，逆対称成 分を含むような荷重分布に対して，ある程度の曲げ剛性 を与えることは，変形および付加張力の低減に非常に効 
果的であることが分かる。また部分荷重などによって生 じる大きい変形は，プレストレスを増加させることに よって抑えることも可能であるが，非常に不経済になり やすく，不都合となる場合が多い。前述のごとく吊り屋 根構造はプレストレスの変化によってその力学的挙動は 非常に異なる性状を示す。初期ひずみ $\varepsilon=1 / 10^{4}$ の場合 になると, 1 方向のみ曲げ剛性を与えても $\left(\beta_{Y}=\infty\right)$ 変 位および張力の追加成分の低減に非常に効果的であり, 構造物に作用するプレストレスの量が非常に小さい場 合, 薄さ比 $\beta$ による構造物の力学的性状もより大きく 変化することが分かる(Fig. 19)。

半面および $1 / 4$ 面荷重分布におけるプレストレスとサ グおよびライズ比 $f$ の変化に伴う特定点の変位の変化 状態がFig. 20 に示されている。前述のごとくこのよう な局部的な荷重分布ケースになると, 薄さ比 $\beta$ の影響 が大きく現れており，プレストレスおよび形状の変化に より,その変化状態が非常に異なっていることが分かる。 結果として，サグおよびライズ比とプレストレスが小さ くなるにつれて， $\beta$ に上る変位の変化状態が一段之著し くなっており，このような場合に構成材にある程度の曲 げ剛性を与えることがより効果的であることがいえる。

吊り屋根構造においては変形や張力の処理問題が設計 上重要なポイントとなるが，このように半剛性の概念を 導入すると, 屋根面の剛性確保という面だけでなく, 引 張構造の有効性を保ちながら，非対称変形に不利な吊り 屋根構造の欠点を補うことができる。また屋根面の水平 力あるいはそれから生じる大きな曲げモーメントの処理 に必要な境界構造の断面も最小限に押さえることも可能 である。

\section{4. 結 論}

以上軸対称回転体シェルおよび半剛性吊り屋根構造を 取り上げ, 主として薄さ比の変化による構造物の力学的 性状の変化状態に関する検討を行った。構造形式にかか わらず，外力の作用の元で生じる存在応力が軸方向力の みであることは非常に合理的であり，設計上理想的な目 標を与えるものであるが, 実際には不可能な場合が多く, 曲げ状態を伴うのが一般的である。このような曲げ状態 は構成要素の曲げ剛性に大きく依存しでう, 構成要素 に曲げ剛性を与えることは作用外力に対する抵抗能力の 向上, 変形および灾力の低減, 張力構造における形態上 の有利性などを含む構造特性の改善に効果的であると推 察される。

\section{参考文献}

1) Stricklin, J. A., et al. : Nonlinear Analysis of Shells of Revolution by the Matrix Displacement Method, AIAA J., Vol. 6, No. 12, pp. 2306 2312, 1968.

2) Cantin, G. : Rigid Body Motions in Curved Finite Elements, AIAA J., Vol.8, No.7, pp.1252 1255, 1970.

3) Mebane; P. M. \& Stricklin, J. A. : Implicit Rigid Body Motion in Curved Finite Elements, AIAA J., Vol.9, No. 2, pp. 344 345, 1971.

4) Ashwell, D.G. \& Gallagher, R. H. : Finite Elements for Thin Shells and Curved Members, John Wiley \& Sons, Ltd., 1976.

5) Koiter, W. T. : On the Nonlinear Theory of Thin Elastic Shells, Proc. Kon. Ned. Ak. Wet., Amsterdam, B69, 1966.

6) Sanders, J. L. : Nonlinear Theories for Thin Shells, Quart. Appl. Math., Vol. 21, No. 1, pp. 21 36, 1963.

7) Frei Otto: Tensile Structure Vol.2, MIT Press, 1969.

8) Murray, K.H. : Comments on the Convergence of Finite Element Solutions, AIAA J., Vol.8, No.4, pp.815 816, 1971.

9) Mollmann, H. : A Study in the Theory of Suspension Structures, Akademisk Forlog, Denmark, 1965.

10) Tsuboi, Y. \& Kawaguchi, M. : Design Problems of a Suspension Roof Structure, Rep. Inst. Ind. Sci. Univ. Tokyo, Vol. 15, No.2, 1965.

11) Kawaguchi, M. \& Chin, Y. : On Nonlinearity of Prestressed Suspension Roofs, Rep. of Tech. College of Hosei Univ., No.17, Tokyo, 1968.

12) Schleyer, F.-K. : Die Berechnung von Seilwerken, Hanging Roofs, Proc. IASS Colloquium, Paris, pp. 56 $\sim 61,1962$.

13) Schleyer, F.-K. : Die Berechnung von Seilnetzen, Hanging Roofs, Proc. IASS Colloquium, Paris, pp. 48 -55, 1962.

14) Kawaguchi, M. \& Abe, M. : Study and Realization of a Hybrid Hanging Roof, Spatial Roof Strs., Proc. IASS Symposium, Dortmund, pp. 194 211, 1984.

15) Siev, A., et al. : Shapes of Suspended Roofs Hanging Roofs, Proc. IASS Colloquium, Paris, pp. 42 47, 1962.

16) Flügge, W. : Stresses in Shells, Springer-Verlag, 1973.

17) Zienkiewicz, O.C. : The Finite Element Method in Engineering Science, McGraw-Hill, 1971.

（1991 年 6 月 10 日原稿受理, 1992 年 1 月 29 日採用決定 